\title{
Award-winning papers in 2020
}

Papers published in Engineering History and Heritage are eligible for awards from the Institution of Civil Engineers. Papers from any of the ICE journals can be nominated for several awards. In addition, each journal has awards dedicated to their specific subject area.

On Friday 15 October 2021, ICE president Rachel Skinner presented awards to the following papers published in Engineering History and Heritage in 2020. The Editorial Panel nominated their best papers and an awards committee chaired by Tim Broyd allocated the awards.

\section{Overseas Prize (Mokshagundam Visvesvaraya Award)}

The Overseas Prize (Mokshagundam Visvesvaraya Award), presented to the best papers written by overseas authors or covering an overseas project, was awarded to Ghoshal (2020).

\begin{abstract}
Howrah Bridge completes its 75 years of service for the populace of the twin Indian cities of Calcutta (now Kolkata) and Howrah and is considered as the icon of the city. The imposing and heavily built balanced-cantilever suspension bridge has held the fancy of the city population ever since its construction. Calcutta, as it was previously known, was built on the bank away from the mainland and therefore had to depend on the main railway station at Howrah on the western bank as the entrance to the city. The bridge has thus become its main link to the mainland in the west and north of India. The present bridge was preceded by a floating bridge on pontoons that served for an astonishing 70 years. Almost 35 years of deliberations, planning and tender invitations had proceeded before the bridge construction was started, only to be completed in a period of 6 years - an amazing feat. The planning and design of the bridge incorporated features addressing future maintenance needs and adjustments that have kept the structure in perfect shape.
\end{abstract}

\section{Thomas Telford Premium Prize}

The Thomas Telford Premium Prize, presented for the best paper published in Engineering History and Heritage, was awarded to Duguid et al. (2020).

\begin{abstract}
The Ordsall Chord is a new railway connecting the main-line stations in Manchester, UK, for the first time, reducing congestion, introducing new passenger services and bringing significant economic benefits. The new railway intersects the line of George Stephenson's 1830 Liverpool and Manchester Railway and connects to two further nineteenth-century railway viaducts. It had a significant physical and visual impact on highly sensitive heritage assets. This first part of a pair of companion papers summarises the project and explains the history of the heritage structures, the consent process and the taken overall approach to conservation architecture and engineering. The design carefully considered the physical, visual and contextual relationship between old and new structures. This paper summarises the structural monitoring work undertaken on the existing brick railway. Other significant works, such as demolition, underpinning and refurbishment of historic metal bridges, are presented and explained. The paper summarises some of the building recording, archaeological investigation and public-realm landscaping works undertaken.
\end{abstract}

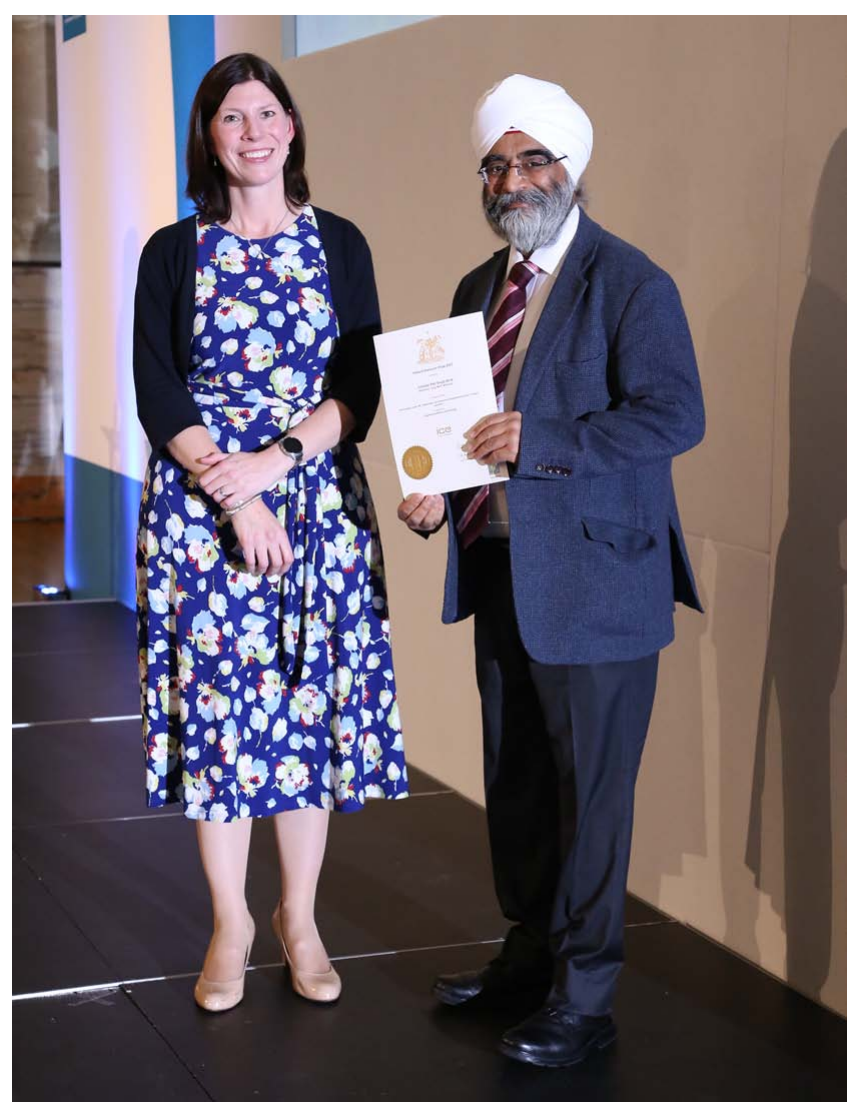

Figure 1. ICE President Rachel Skinner with Thomas Telford Premium Prize winner Jutinder Birdi

\section{REFERENCES}

Duguid B, Bone B and Birdi J (2020) The Ordsall Chord, UK: conservation architecture and engineering - part 1: project overview. Proceedings of the Institution of Civil Engineers - Engineering History and Heritage 173(2): 43-59, https://doi.org/10.1680/jenhh.19.00009.

Ghoshal A (2020) Howrah Bridge: icon of a 330-year-old city in India part I: history, planning and design. Proceedings of the Institution of Civil Engineers - Engineering History and Heritage 173(3): 117-128, https://doi.org/10.1680/jenhh.19.00017. 